\title{
The Oncogenic Roles of JC Virus T Antigen in Breast Carcinogenesis
}

\author{
Hua-chuan Zheng ${ }^{1 *}$, Ying $E^{2}$, Zheng-guo Cui ${ }^{3}$, Shuang Zhao ${ }^{1}$ and Yong Zhang ${ }^{4}$ \\ ${ }^{1}$ Department of Oncology and Experimental Center, The Affiliated Hospital of Chengde Medical University, Chengde, China, \\ ${ }^{2}$ Department of Oncology, Liaoning Cancer Hospital, Shenyang, China, ${ }^{3}$ Department of Environmental Health, University of Fukui \\ School of Medical Science, Fukui, Japan, ${ }^{4}$ Department of Pathology, Liaoning Cancer Hospital, Shenyang, China
}

Purpose: $\mathrm{JC}$ virus (JCV) infects $80-90 \%$ of the population and results in progressive multifocal leukoencephalopathy upon immunodeficiency. The study aimed to pathologically clarify the oncogenic roles of $\mathrm{T}$ antigen in human breast cancers.

Methods: Breast cancer, dysplasia, and normal tissues were examined for $T$ antigen of JCV by nested and real-time PCR. The positive rate or copy number of T antigen was compared with clinicopathological parameters of breast cancer. JCV existence was morphologically detected by immunohistochemistry and in situ PCR. T antigen was examined by Western blot using frozen samples of breast cancer and paired normal tissues.

OPEN ACCESS

Edited by:

Tianhui Chen,

Zhejiang Cancer Hospital (CAS), China

Reviewed by:

Vikram Srivastava,

lowa State University, United States

Peng Huang,

Okayama University, Japan

*Correspondence:

Hua-chuan Zheng

zheng_huachuan@hotmail.com

Specialty section:

This article was submitted to

Molecular Diagnostics and Therapeutics,

a section of the journal

Frontiers in Molecular Biosciences

Received: 29 March 2021

Accepted: 13 July 2021

Published: 12 August 2021

Citation:

Zheng $H, E Y, C$ Cui Z, Zhao $S$ and Zhang Y (2021) The Oncogenic Roles

of $\mathrm{JC}$ Virus T Antigen in

Breast Carcinogenesis.

Front. Mol. Biosci. 8:687444.

doi: 10.3389/fmolb.2021.687444
Results: According to nested PCR, the positive rate of breast ductal or lobular carcinoma was lower than that of normal tissue $(p<0.05)$. T antigen existence was negatively correlated with E-cadherin expression and triple-negative breast cancer $(p<0.05)$, but positively correlated with lymph node metastasis and estrogen receptor and progestogen receptor expression $(p<0.05)$. Quantitative PCR showed that JCV copies were gradually decreased from normal, dysplasia to cancer tissues $(p<0.05)$. JCVT antigen copy number was lower in ductal adenocarcinoma than in normal tissue $(p<0.05)$, in line with in situ PCR and immunohistochemistry. JCV copies were negatively correlated with tumor size and E-cadherin expression $(p<0.05)$, but positively correlated with $G$ grading of breast cancer $(p<0.05)$. Western blot also indicated weaker $T$ antigen expression in breast cancer than normal tissues $(p<0.05)$.

Conclusion: JCVT antigen might play an important role in breast carcinogenesis. It can be employed as a molecular marker for the differentiation and aggressive behaviors of breast cancer.

Keywords: JC virus T antigen, oncogenesis, breast cancer, dysplasia, pathological behaviors

\section{INTRODUCTION}

Breast cancer is the leading cause of cancer death among women, even in less developed countries (Coughlin, 2019). Environmental, hereditary, and genetic backgrounds are considered as the most important factors for carcinogenesis and the subsequent progression of breast cancer. Among environmental factors, viral infection is associated with about $15-20 \%$ of all cancers (FahadUllah, 2019). 
JC virus (JCV) is a member of the polyomavirus family (Assetta and Atwood, 2017) and has a circular and doublestranded DNA genome. The early region encodes $\mathrm{T}$ antigen (Reiss and Khalili, 2003), a large phosphoprotein that binds to the viral replication region to promote double helix unwinding and recruitment of DNA synthesis proteins. The late region encodes the capsid structural proteins VP1, VP2 and, VP3 and agnoprotein (Reiss and Khalili, 2003; Saxena et al., 2021). Serologically, there is asymptomatic JCV infection in $80-90 \%$ of the adult population (Ahye et al., 2020). JCV enters the human body through both digestive and respiratory tracts and persists quiescent in the kidney and lymphoid tissues (White and Khalili, 2005; Delbue et al., 2017; Dwyer et al., 2021). However, it may be activated under immunosuppressive conditions, resulting in progressive multifocal leukoencephalopathy (PML) (Reiss and Khalili, 2003; Delbue et al., 2017; Ahye et al., 2020; Dwyer et al., 2021; Saxena et al., 2021). During permissive infection, replication of viral DNA can cause lytic infection, but in nonpermissive cells, either abortive infection or cell transformation is the outcome (Delbue et al., 2017; Ahye et al., 2020; Saxena et al., 2021). JCV can transform cells, which display rapid growth and division, prolongation of lifespan, anchorage-dependent growth, chromosomal instability, and dense foci formation in culture (Eash et al., 2004; White and Khalili, 2005).

Intravenous or intracranial inoculation of JCV has been found to cause astrocytomas, glioblastomas, neuroblastomas, and medulloblastomas (Miller et al., 1984; Hayashi et al., 2001). In addition, transgenic mice expressing $\mathrm{T}$ antigen developed pituitary adenomas or malignant peripheral nerve sheath tumors (London et al., 1978; Del Valle and Khalili, 2021). In previous studies, we established transgenic mice and found that $\mathrm{T}$ antigen induced lens tumors and lung cancer (Gou et al., 2015; Noguchi et al., 2013). Recently, JCV was demonstrated to correlate with colorectal, gastric, prostatic, and esophageal cancers, brain tumors, lung cancer, and B cell lymphomas (Del Valle et al., 2005; Zheng et al., 2007a; Murai et al., 2007; Kutsuna et al., 2008; Ramamoorthy et al., 2011; Shen et al., 2011; Wang et al., 2012; Noguchi et al., 2013; Anzivino et al., 2015; MalekpourAfshar et al., 2016). The oncogenesis of JCV mainly centers on $\mathrm{T}$ antigen. $\mathrm{T}$ antigen can inactivate $\mathrm{p} 53$ and $\mathrm{Rb}$ and disrupt the Wnt signaling pathway (Piña-Oviedo et al., 2006). The encoding genes of JCV are known to be preferentially expressed in astrocytes and oligodendrocytes of the human brain because these cells contain specific transcriptional factors (NF-1, Sp1, S $\mu b p-2$, and Pura) (Piña-Oviedo et al., 2006). Reportedly, investigators have identified JCV in the liver, kidney, spleen, bone marrow, bladder, prostate, and tonsils by PCR (Zheng et al., 2009). Here, we examined the existence and copy number of JCV in breast cancer, dysplasia, and normal tissues by nested PCR, real-time PCR, immunohistochemistry, and in situ PCR and compared JCV existence with clinicopathological parameters of breast cancer.

\section{MATERIALS AND METHODS}

\section{Subjects}

Formalin-fixed and paraffin-embedded breast cancer $(\mathrm{n}=112)$, breast dysplasia $(n=18)$, and normal breast $(n=48)$ tissues were sampled from surgical materials in The Affiliated Hospital of Chengde Medical University and Liaoning Cancer Hospital. Fresh samples of breast cancer and paired normal tissues $(n=$ 10) were collected from both hospitals. The cancer patients did not receive a neoadjuvant before surgical operation. They signed informed consent. The ethics committees of these hospitals approved the study.

\section{DNA Extraction and Checking}

Paraffin-embedded blocks were incised into $10-\mu \mathrm{m}$-thick sections, microdissected under the guidance of HE slides, and subjected to deparaffinization and rehydration. DNA was extracted by the traditional proteinase $\mathrm{K} /$ phenol/chloroform method. To check DNA integrity, we amplified tissue DNA by targeting $\beta$-globin: Forward; 5'-ACACAACTGTGTTCACTAGC-3'; backward; $5^{\prime}$ GTCTCCTTAAACCTGTCTTG-3' ${ }^{\prime}$. PCR condition was described as follows: 30 cycles of denaturation at $95^{\circ} \mathrm{C}$ for $20 \mathrm{~s}$, annealing at $55^{\circ} \mathrm{C}$ for $35 \mathrm{~s}$, and extension at $72^{\circ} \mathrm{C}$ for $20 \mathrm{~s}$. DNA-free amplification was employed as a negative control.

\section{Nested PCR}

PCR was carried out by targeting $T$ antigen. T1 (5'-TGGCCTG TAAAGTTCTAGG CA $-3^{\prime}$ and T2 (5'-GCAGAGTCAAGGGAT TTACCTTC- $3^{\prime}$ ) primers were used for the 1 st PCR, whereas T1 and T3 ( $5^{\prime}$-AGCAACCTTGATTGCTTAAGAGA- $\left.3^{\prime}\right)$ were used for the 2nd PCR. The $20 \mu \mathrm{l}$ of reaction mixtures contained $0.1 \mu \mathrm{l}$ of Ex Taq HS (TaKaRa) with $2.0 \mathrm{mM}$ of $\mathrm{MgCl}_{2}, 2.0 \mu \mathrm{l} \times 10$ PCR buffer, $2.0 \mu \mathrm{l}$ of dNTP mixture, $1 \mu \mathrm{M}$ of each primer, and $200 \mathrm{ng}$ of DNA. The PCR process was 32 cycles of denaturation at $95^{\circ} \mathrm{C}$ for $20 \mathrm{~s}$, annealing at $56^{\circ} \mathrm{C}$ for $20 \mathrm{~s}$, and extension at $72^{\circ} \mathrm{C}$ for $20 \mathrm{~s}$. Nested PCR was carried out using $1 \%$ (volume) of the first amplicon. DNA-free amplification was employed as a negative control.

\section{Real-Time PCR}

SYBR fluorescence PCR was used to quantify JCV copies using the Bio-Rad PCR system. A plasmid of PBS-JCV T antigen was serially diluted for standard reference. These standard and sample DNAs were amplified by targeting $T$ antigen: Forward: $5^{\prime}$-GCC ACCCCAGCCATATATTG- $3^{\prime}$ and backward: $5^{\prime}$-GTTGACAGT ATCCATATGACCAGAGAA- $3^{\prime}$. In total, the $20 \mu \mathrm{l}$ reaction mixture contained $10.0 \mu \mathrm{l}$ of $\operatorname{TaqMan}^{\circledR}(\times 2)$ with $1.8 \mu \mathrm{l}$ $(10 \mu \mathrm{M})$ of each primer and $80 \mathrm{ng}$ of DNA. The PCR protocol was 55 cycles of denaturation at $95^{\circ} \mathrm{C}$ for $25 \mathrm{~s}$, annealing at $55^{\circ} \mathrm{C}$ for $50 \mathrm{~s}$, and extension at $72^{\circ} \mathrm{C}$ or $25 \mathrm{~s}$.

\section{Immunohistochemistry}

Serial sections were deparaffinized with xylene, rehydrated with alcohol, and subjected to antigen retrieval by irradiation in target retrieval solution (TRS, DAKO, CA, United States) for $5 \mathrm{~min}$ with a microwave oven. Five percent BSA was then applied to incubation for $5 \mathrm{~min}$ to prevent non-specific binding. The sections were incubated with anti-SV $40 \mathrm{~T}$ antigen antibody (Calbiochem, United States; 1:100) for $20 \mathrm{~min}$ and then treated with the anti-mouse Envision-PO (1:100, DAKO, CA, United States) antibody for $20 \mathrm{~min}$. Incubation was performed in a microwave oven for intermittent irradiation as described previously (Gou et al., 2015). After each treatment, the slides were 
washed with TBST (10 mM of Tris- $\mathrm{HCl}, 150 \mathrm{mM}$ of $\mathrm{NaCl}, 0.1 \%$ Tween 20) three times for $5 \mathrm{~min}$. All slides were colored with 3 , 3 '-diaminobenzidine and counterstained with Mayer's hematoxylin. Omission of the primary antibody was used as a negative control.

\section{In Situ PCR}

A $10-\mu \mathrm{m}$-thick section was prepared with proteinase $\mathrm{K}$ for $15 \mathrm{~min}$. After TBS washing, the tissue slide was fixed with $4 \%$ paraformaldehyde and then washed with $2 \times$ SSC. After that, $100 \mu \mathrm{l}$ of PCR mixture $(0.2 \mu \mathrm{M}$ of primers, $0.125 \mathrm{nM}$ of digoxigenin-11-dUTP, $2.5 \mathrm{mM}$ of $\mathrm{MgCl}_{2}, 1 \times$ PCR buffer, $6.25 \mathrm{U}$ of Taq polymerase) was put into a membrane, sealing on the tissue. PCR amplification was performed at the condition: Denaturation at $94^{\circ} \mathrm{C}$ for $3 \mathrm{~min}$, followed by 20 cycles of $92^{\circ} \mathrm{C}$ for $15 \mathrm{~s}, 55^{\circ} \mathrm{C}$ for $20 \mathrm{~s}$, and $72^{\circ} \mathrm{C}$ for $30 \mathrm{~s}$ and final extension at $72^{\circ} \mathrm{C}$ for $7 \mathrm{~min}$. The primers were forward: $5^{\prime}$-AGGTAGGCCTTTGGTCTAA- $3^{\prime}$ and backward: $5^{\prime}$-TGCCTAGAACTTTACAGG-3'. After that, the tissue was washed with $2 \times$ SSC and incubated with blocking solution $(100 \mu \mathrm{g} / \mathrm{ml}$ of Salmon testis DNA, $100 \mu \mathrm{g} / \mathrm{ml}$ of yeast tRNA, and $5 \% \mathrm{BSA}$ ) for $1 \mathrm{~h}$. Subsequently, the sections were reacted with antidigoxigenin and AP (alkaline phosphatase)-conjugated antibody (Roche, 1:500) for $90 \mathrm{~min}$. After being washed for $5 \mathrm{~min}$ and immersed in solution II (100 mM of Tris-HCl, $\mathrm{pH} 9.5,100 \mathrm{mM}$ of $\mathrm{NaCl}$, and $50 \mathrm{mM}$ of $\mathrm{MgCl}_{2}$ ) for $15 \mathrm{~min}$, the positive signal was colored using NBP/BCIP. Finally, methyl green was used for counterstaining.

\section{Western Blot}

We homogenized breast cancer and normal tissues in RIPA lysis buffer, and a protein assay was performed using Kaumas brilliant blue. A $50 \mu \mathrm{g}$ protein/sample was subjected to $10 \%$ SDS-PAGE electrophoresis and electrically transferred to a PVDF membrane, which was incubated with $5 \%$ bovine serum albumin (BSA) in TBST, and then with anti-SV40 T antigen (1:200; Santa Cruz) or rabbit anti-GAPDH (1:2,000, CST) antibody. The membranes were washed with TBST and incubated with anti-rabbit or antimouse HRP-conjugated secondary antibody (DAKO, 1:1,000). Bands were visualized with Azure Biosystem C300 by an ECL detection kit.

\section{Statistical Analysis}

SPSS v. 26.0 software was used for statistical analysis. Statistical analysis was carried out using Fisher's test for the comparison of positive rates and Mann-Whitney $U$ for the comparison of means. A $p$ value $<0.05$ was statistically regarded as significant.

\section{RESULTS}

As indicated in Figure 1A, we used general PCR of $\beta$-globin as quality control. We observed positive bands in all samples. Nested PCR indicated that the positive rate of $\mathrm{T}$ antigen was lower in breast ductal or lobular carcinoma than normal tissues (Figure 1B, $p<0.05$ ). As shown in Table 1, T antigen existence was negatively correlated with E-cadherin expression $(64.3$ vs. $30.3 \%, p<0.05)$ and triple-negative breast cancer (TNBC, 52.8 vs. $18.2 \%, p<0.05$ ), but positively correlated with lymph node metastasis (42.9 vs. $64.7 \%, p<0.05$ ), estrogen receptor (ER) expression (25.0 vs. $55.0 \%, p<0.05$ ), and progestogen receptor (PR) expression (26.1 vs. $55.8 \%, p<0.05$ ).

Real-time PCR showed that $\mathrm{T}$ antigen copies were gradually decreased from normal, dysplasia to cancer tissues (Figure 2A, $p<0.05)$. They were lower in ductal adenocarcinoma than in normal tissues (Figure 2B, $p<0.05$ ). They were negatively correlated with tumor size (Figure 2C, $p<0.05$ ) and E-cadherin expression (Figure 2E) and positively correlated with $\mathrm{G}$ grading of breast cancer (Figure 2D, $p<0.05$ ). In situ PCR demonstrated that positive cells were detectable in breast ductal and lobular epithelium, but no or weak signal was seen in breast cancer, in line with immunohistochemistry (Figure 3). Meanwhile, a weaker $\mathrm{T}$ antigen expression was seen in breast cancer than that in paired normal tissues by Western blot (Figure 4).

\section{DISCUSSION}

Cellular malignant transformation needs a series of genetic or epigenetic accumulation, including oncogene activation or overexpression (Del Valle and Khalili, 2021). Although JCV is a highly neurotropic virus and induces brain tumors, JCV DNA was discovered in the respiratory and the upper and lower gastrointestinal tracts (Ahye et al., 2020). Furthermore, detection of JCV in renal tubules and tonsil lymphocytes indicated JCV persistence in a quiescent state of these cells during latency and infection of other cells upon immune suppression (Zheng et al., 2007b). Upon its entrance into cells, $\mathrm{T}$ antigen can inactivate nuclear p53 and pRb proteins to disrupt the cell cycle (Khalili et al., 2006). It can also suppress the Wnt pathway via $\beta$-catenin degradation and disrupt cellular IGF-IR signaling pathways (Reviriego-Mendoza and Frisque, 2011). Additionally, $T$ antigen decreased Bag-3 expression for apoptotic suppression by blocking the interaction of AP2 with the Bag3 promoter (Sariyer et al., 2012).

Guillory et al. (2010) established a breast cancer model of the polyoma middle $\mathrm{T}$ antigen transgenic mouse. Tzeng et al. (1993) injected whey acidic protein (WAP)-SV-T antigen DNA into fertilized mouse eggs and found that female mice developed breast cancer with high frequency. It was very interesting that the inactivation of PTEN in CK19-positive cells caused triple-negative breast lobular carcinoma (Zhao et al., 2017). Reddi et al. (2019) reported that diffuse large $\mathrm{B}$ cell lymphoma appeared secondary to JCV in PML. Querido et al. (2020)observed high-grade urothelial carcinoma in a kidney transplant recipient after JCV-related nephropathy. Malhotra et al. (2016) found that JCV seropositivity was positively associated with a high lung cancer risk in the nonsmoking population. Many investigators did not detect JCV in breast cancer tissue samples (Hogan et al., 1983; Antonsson et al., 2012; Dowran et al., 2019). However, Hachana et al. (2012) detected that JCV T antigen DNA was in invasive ductal carcinomas $(28 / 112$, $25.0 \%$ ) but not in invasive lobular and medullary carcinomas. In this study, we found that JCV T antigen existence was gradually decreased during breast carcinogenesis at both the DNA and protein level and negatively correlated with $\mathrm{T}$ staging of breast cancer. No differences in $\mathrm{T}$ antigen DNA and protein were found in ductal adenocarcinomas or lobular adenocarcinomas. This indicated that it might be difficult 


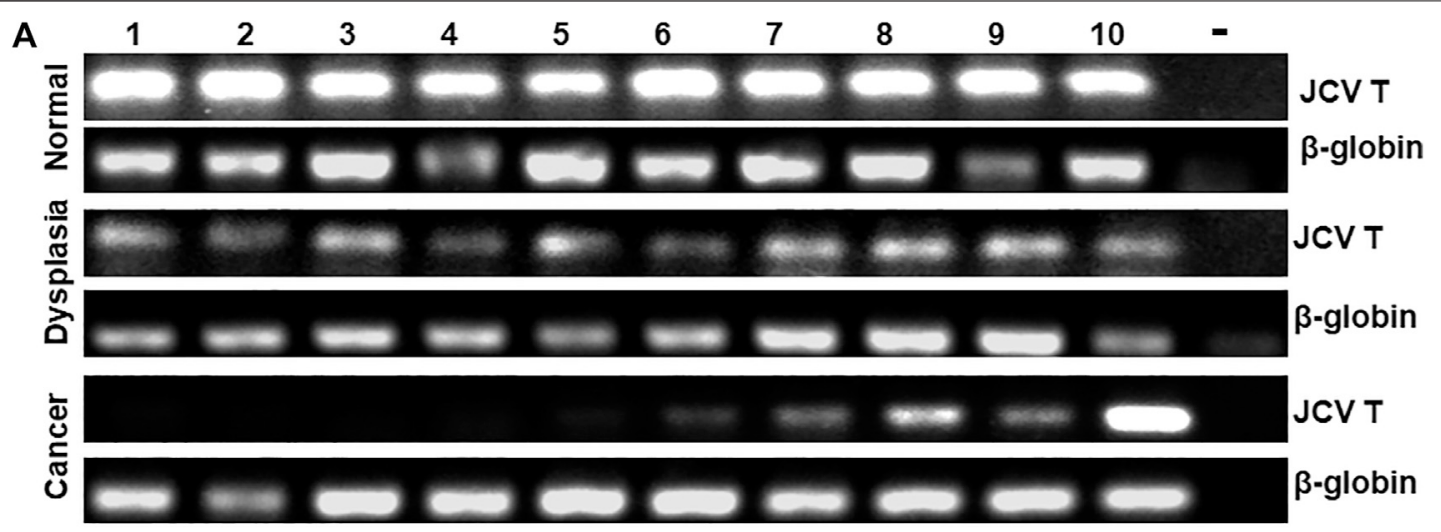

B

\begin{tabular}{|l|c|c|c|c|l|}
\hline & $\mathrm{n}$ & Positive & Negative & PR (\%) & p value \\
\hline Normal breast & 48 & 38 & 10 & 79.2 & \\
\hline Dysplasia & 18 & 14 & 4 & 77.8 & \\
\hline Ductal cancer & 68 & 31 & 37 & 45.6 & $<0.001$ \\
\hline Lobular cancer & 44 & 21 & 23 & 47.7 & 0.002 \\
\hline
\end{tabular}

FIGURE 1 | Detection of JCV T antigen in breast carcinogenesis. $\beta$-globin was positive in all cases of normal tissue, dysplasia, and cancer of the breast. T antigen was positive in some cancer cases by nested PCR (A). The positive rates of JCV T antigen were compared between cancer, dysplasia, and normal tissue (B). -, negative control; PR, positive rate.
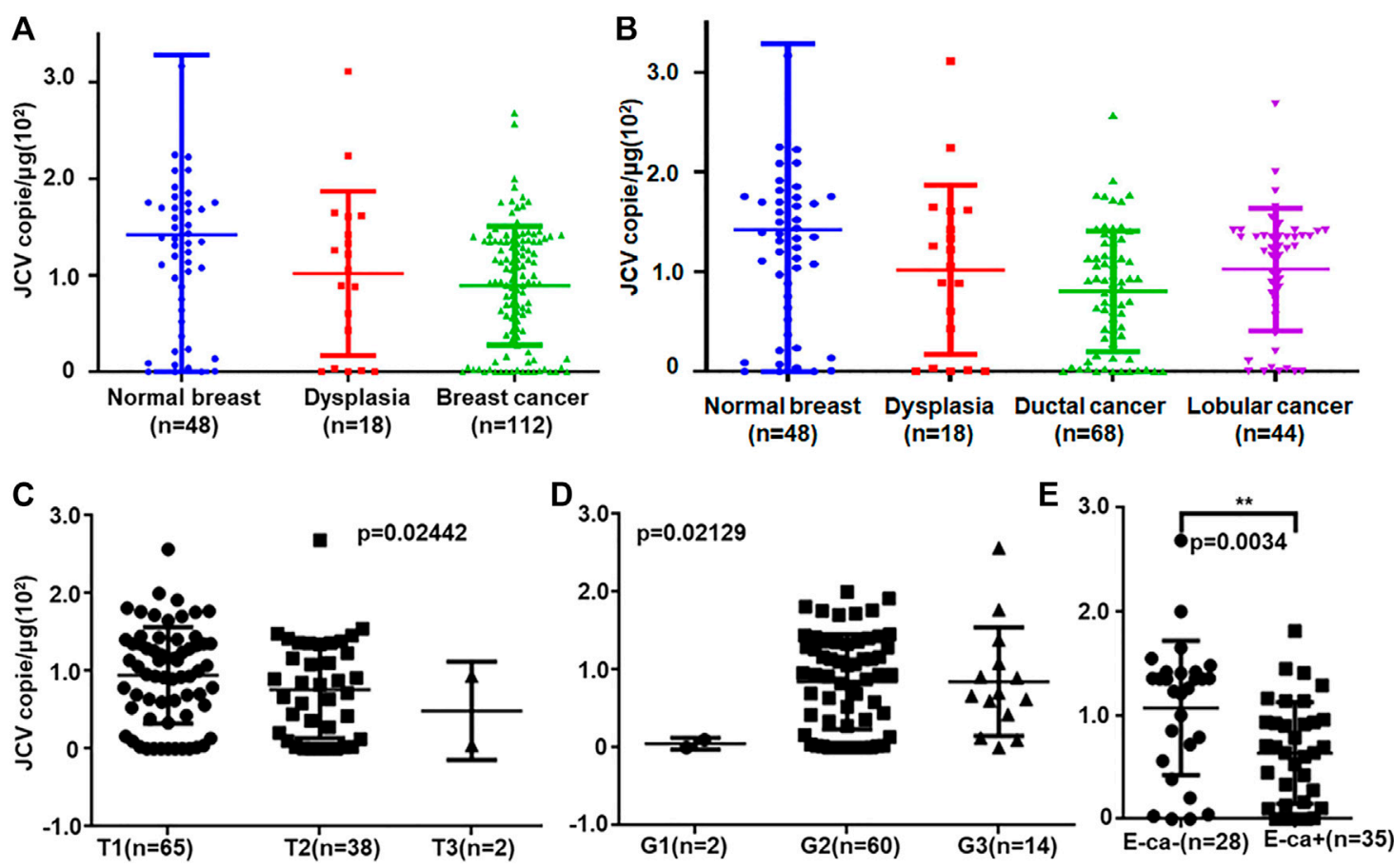

FIGURE 2 | JCV T antigen loads in breast cancers. T antigen copies were measured and calculated in normal, dysplasia, and cancer tissues by real-time PCR (A). The copies were analyzed between ductal and lobular cancers (B). They were also compared with T staging (C), G grading (D), and E-cadherin expression (E). E-cad, E-cadherin expression. 
TABLE 1 | The correlation between JCV T antigen existence and clinicopathological features of breast cancer

\begin{tabular}{|c|c|c|c|c|c|}
\hline \multirow[t]{2}{*}{ Parameters } & \multirow[t]{2}{*}{$\mathbf{n}$} & \multicolumn{2}{|c|}{ JCV T antigen } & \multirow[t]{2}{*}{$x^{2}$} & \multirow[t]{2}{*}{$p$ value } \\
\hline & & - & + & & \\
\hline N staging & 97 & & & 4.217 & 0.040 \\
\hline- & & $36(57.1 \%)$ & 27 (42.9\%) & & \\
\hline+ & & $12(35.3 \%)$ & $22(64.7 \%)$ & & \\
\hline E-cadherin expression & 61 & & & 7.044 & 0.008 \\
\hline- & & $10(35.7 \%)$ & $18(64.3 \%)$ & & \\
\hline+ & & $23(69.7 \%)$ & 10 (30.3\%) & & \\
\hline ER expression & 100 & & & 5.762 & 0.016 \\
\hline- & & $15(75.0 \%)$ & 5 (25.0\%) & & \\
\hline+ & & $36(45.0 \%)$ & $44(55.0 \%)$ & & \\
\hline PR expression & 100 & & & 6.275 & 0.012 \\
\hline- & & 17 (73.9\%) & $6(26.1 \%)$ & & \\
\hline+ & & $34(44.2 \%)$ & 43 (55.8\%) & & \\
\hline TNBC & 101 & & & 4.697 & 0.030 \\
\hline- & & $42(47.2 \%)$ & 47 (52.8\%) & & \\
\hline+ & & $9(81.8 \%)$ & $2(18.2 \%)$ & & \\
\hline
\end{tabular}

$E R$, estrogen receptor; $P R$, progesterone receptor; TNBC, triple-negative breast cancer

for JCV infection, genomic insertion, and subsequent translation of T antigen during breast carcinogenesis and subsequent growth. However, it also cannot deny the oncogenic role of $\mathrm{T}$ antigen in breast cancer because it can be detected in breast cancer and its overexpression can induce breast cancer. In line with Hachana's report (Hachana et al., 2012), we also found that JCV DNA presence correlated with TNBC. Thereby, it was believed that T antigen might be closely linked to the tumorigenesis of TNBC.

JCV T antigen was involved in colorectal carcinogenesis and liver metastasis (Sinagra et al., 2014; Shoraka et al., 2020; Vilkin and Niv, 2011). Reportedly, JCV T antigen stabilized $\beta$-catenin for its nuclear translocation to initiate cancer proliferation and development (Nosho et al., 2009). Our previous study has demonstrated that lung cancers with higher JCV copy numbers displayed high proliferation and downregulation of cell adhesion, mediated by membrane $\beta$-catenin (Zheng et al., 2007a). Donadoni et al. (2018) found that mouse T antigenoverexpressing medulloblastoma cells had survival capacity, radiation resistance, a high colony formation, and a strong double-strand DNA break repair. Noch et al. (2012) demonstrated that $\mathrm{T}$ antigen promoted the expression of hexokinase 2 and the pentose phosphate enzyme, transaldolase-1 for glycolysis, and pentose catabolism in medulloblastoma cells. Ksiaa et al. (2010) found that JCV presence was correlated with the patient's age and differentiation and abnormal methylation of tumor suppressor genes of gastric cancer. Here, we found that JCV $\mathrm{T}$ antigen was positively correlated with $\mathrm{G}$ grading, $\mathrm{N}$ staging, E-cadherin hypoexpression, and non-TNBC, suggesting that $\mathrm{T}$ antigen existence might be employed to indicate poor differentiation and low E-cadherin-mediated metastasis of breast cancer.

If a virus plays an oncogenic role, it must infect the cells and then encode the oncogenic proteins to disrupt the cell function. According to our findings, we found that JCV copies were different according to tissue types (stomach $<$ lung $<$ breast) because the distinct distribution of its receptors ( $\alpha 2,6$-linked sialic acid and serotonin) determined its different infection (Eash et al., 2004; Elphick et al., 2004; Gee et al., 2006). Geoghegan et al. (2017) showed that non-sialylated glycosaminoglycans served as alternative attachment receptors for the infection of JCV. Nukuzuma et al. (2016) found the suppressive effect of topoisomerase I inhibitors topotecan and $\beta$-lapachone on JCV propagation in human neuroblastoma cells. Adipocyte plasma membrane protein, PI3K $\gamma$, and its regulatory subunit PIK3R5 promoted JCV infection in human glial cells (Clark et al., 2020; Haley et al.,

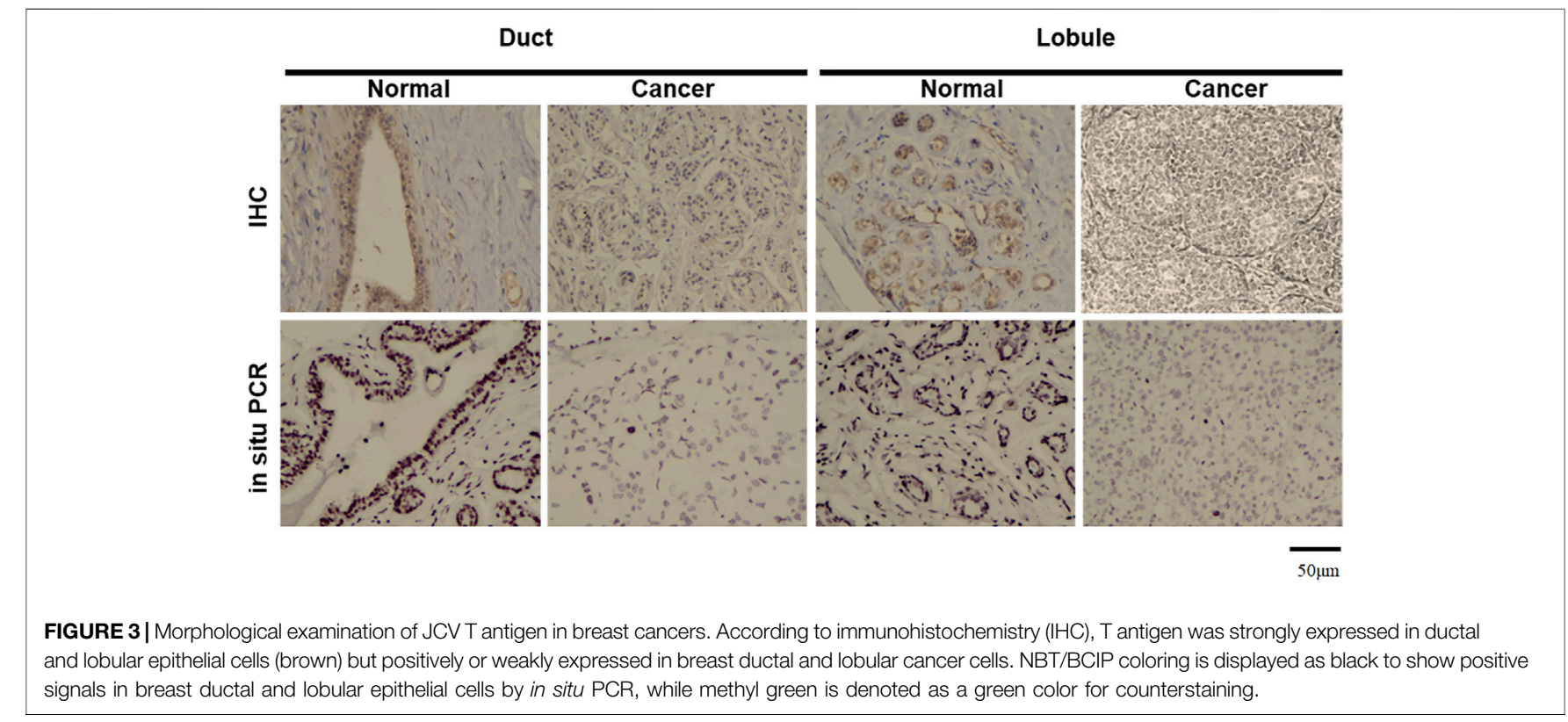



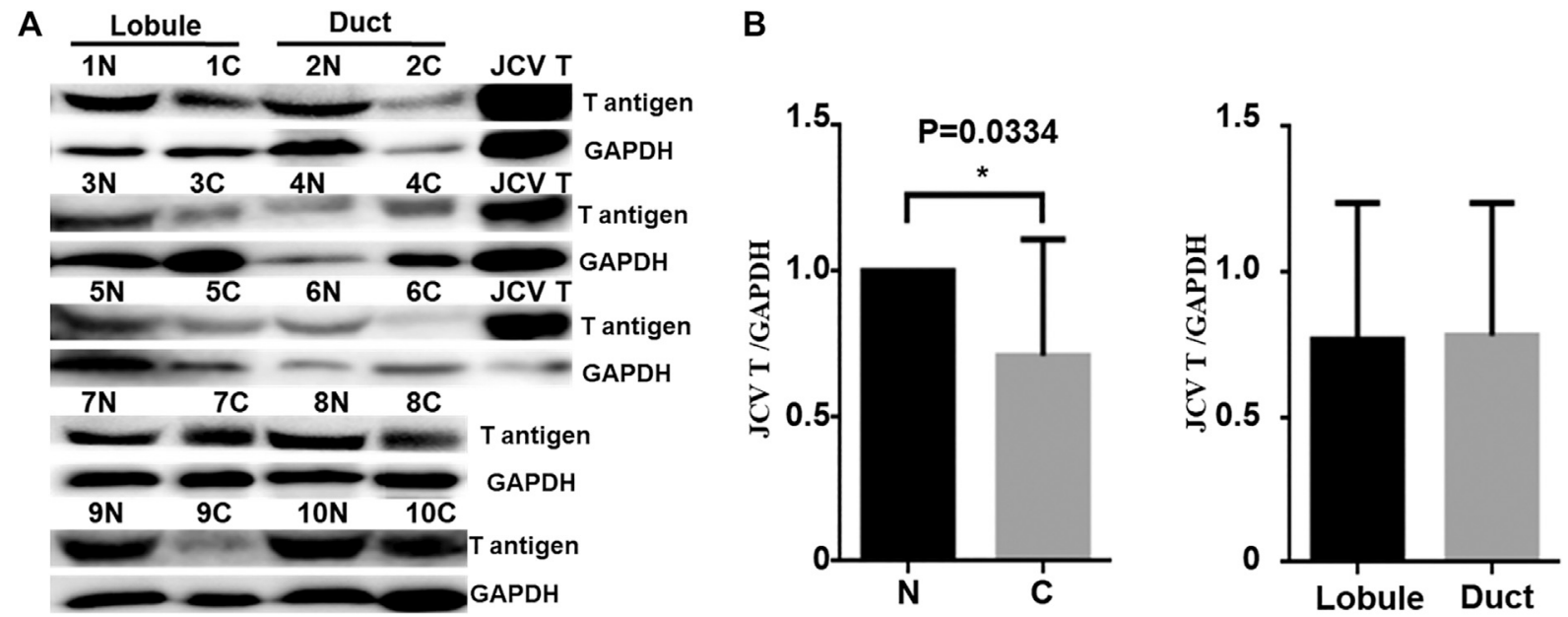

FIGURE 4 | JCV T antigen expression in human breast cancers. T antigen was screened by Western blot (A) and subsequently analyzed by densitometric analysis (B). N, normal; C, cancer. Positive control, spontaneous breast cancer from JCV T antigen transgenic mouse.

2020). Uleri et al. (2011) showed that alternative splicing factor, SF2/ASF, negatively regulated transcription and splicing of JCV genes in glial cells. SF2/ASF hyperexpression induced growth and proliferation of JCV-transformed tumor cells. Either endogenous or ectopic LIP expression mediated the degradation of $\mathrm{T}$ antigen in a JCV-transgenic mouse tumor cell line (Bellizzi et al., 2015). According to our knowledge, the partner proteins of $\mathrm{T}$ antigen might be involved in the cell specificity of JCV T antigen, which will be confirmed in the future. Finally, estrogen and proliferation of lobular glands during breeding might increase the risk of genetic breast cancer.

In conclusion, the JCV T antigen might play an important role in breast carcinogenesis. JCV infection, insertion, transcription, translation, degradation, target, and partner chaperons of its $\mathrm{T}$ antigen might underlie the molecular mechanisms of its tissuespecific carcinogenesis.

\section{DATA AVAILABILITY STATEMENT}

The original contributions presented in the study are included in the article/supplementary materials, further inquiries can be directed to the corresponding author/s.

\section{REFERENCES}

Ahye, N., Bellizzi, A., May, D., and Wollebo, H. S. (2020). The Role of the JC Virus in central Nervous System Tumorigenesis. Int. J. Mol. Sci. 21, 6236. doi:10.3390/ ijms 21176236

Antonsson, A., Bialasiewicz, S., Rockett, R. J., Jacob, K., Bennett, I. C., and Sloots, T. P. (2012). Exploring the Prevalence of Ten Polyomaviruses and Two Herpes Viruses in Breast Cancer. PLoS One 7, e39842. doi:10.1371/ journal.pone.0039842

Anzivino, E., Rodio, D. M., Mischitelli, M., Bellizzi, A., Sciarra, A., Salciccia, S., et al. (2015). High Frequency of JCV DNA Detection in Prostate Cancer Tissues. Cancer Genomics Proteomics 12, 189-200.

\section{ETHICS STATEMENT}

The studies involving human participants were reviewed and approved by The Affiliated Hospital of Chengde Medical University and Liaoning Cancer Hospital. The patients/ participants provided their written informed consent to participate in this study.

\section{AUTHOR CONTRIBUTIONS}

$\mathrm{HZ}$ contributed to the conception of the study, performed the data analyses, and wrote the manuscript; SZ and YZ performed the experiment; YE and ZC contributed significantly to analysis and manuscript preparation.

\section{FUNDING}

This study was supported by the Award for Liaoning Distinguished Professor, Natural Science Foundation of Hebei Province (202130821010436) and the National Natural Scientific Foundation of China (grant no. 81672700).

Assetta, B., and Atwood, W. J. (2017). The Biology of JC Polyomavirus. Biol. Chem. 398, 839-855. doi:10.1515/hsz-2016-0345

Bellizzi, A., White, M. K., and Wollebo, H. S. (2015). Degradation of Polyomavirus JC T-Antigen by Stress Involves the LIP Isoform of C/EBP. Cell Cycle 14, 2075-2079. doi:10.1080/15384101.2015.1042631

Clark, P., Gee, G. V., Albright, B. S., Assetta, B., Han, Y., Atwood, W. J., et al. (2020). Phosphoinositide $3^{\prime}$-Kinase $\gamma$ Facilitates Polyomavirus Infection. Viruses 12, 1190. doi:10.3390/v12101190

Coughlin, S. S. (2019). Epidemiology of Breast Cancer in Women. Adv. Exp. Med. Biol. 1152, 9-29. doi:10.1007/978-3-030-20301-6_2

Del Valle, L., and Khalili, K. (2021). Induction of Brain Tumors by the Archetype Strain of Human Neurotropic JCPyV in a Transgenic Mouse Model. Viruses 13, 162. doi: $10.3390 / \mathrm{v} 13020162$ 
Del Valle, L., White, M. K., Enam, S., Oviedo, S. P. a., Bromer, M. Q., Thomas, R. M., et al. (2005). Detection of JC Virus DNA Sequences and Expression of Viral T Antigen and Agnoprotein in Esophageal Carcinoma. Cancer 103, 516-527. doi:10.1002/cncr.20806

Delbue, S., Comar, M., and Ferrante, P. (2017). Review on the Role of the Human Polyomavirus JC in the Development of Tumors. Infect. Agent Cancer 12, 10. doi:10.1186/s13027-017-0122-0

Donadoni, M., Sariyer, R., Wollebo, H., Bellizzi, A., and Kudret Sariyer, I. (2018). Viral Tumor Antigen Expression Is No Longer Required in Radiation-Resistant Subpopulation of JCV Induced Mouse Medulloblastoma Cells. Genes Cancer 9, 130-141. doi:10.18632/genesandcancer.174

Dowran, R., Joharinia, N., Safaei, A., Bakhtiyarizadeh, S., Alidadi Soleimani, A., Alizadeh, R., et al. (2019). No Detection of EBV, BKV and JCV in Breast Cancer Tissue Samples in Iran. BMC Res. Notes 12, 171. doi:10.1186/s13104-0194178-3

Dwyer, C. M., Jokubaitis, V. G., Stankovich, J., Baker, J., Haartsen, J., Butzkueven, H., et al. (2021). High Rates of JCV Seroconversion in a Large International Cohort of Natalizumab-Treated Patients. Ther. Adv. Neurol. Disord. 14, 1756286421998915. doi:10.1177/1756286421998915

Eash, S., Tavares, R., Stopa, E. G., Robbins, S. H., Brossay, L., and Atwood, W. J. (2004). Differential Distribution of the JC Virus Receptor-type Sialic Acid in normal Human Tissues. Am. J. Pathol. 164, 419-428. doi:10.1016/s00029440(10)63132-x

Elphick, G. F., Querbes, W., Jordan, J. A., Gee, G. V., Eash, S., Manley, K., et al. (2004). The Human Polyomavirus, JCV, Uses Serotonin Receptors to Infect Cells. Science 306, 1380-1383. doi:10.1126/science.1103492

Fahad Ullah, M. (2019). Breast Cancer: Current Perspectives on the Disease Status. Adv. Exp. Med. Biol. 1152, 51-64. doi:10.1007/978-3-030-20301-6_4

Gee, G. V., Dugan, A. S., Tsomaia, N., Mierke, D. F., and Atwood, W. J. (2006). The Role of Sialic Acid in Human Polyomavirus Infections. Glycoconj J. 23, 19-26. doi:10.1007/s10719-006-5434-z

Geoghegan, E. M., Pastrana, D. V., Schowalter, R. M., Ray, U., Gao, W., Ho, M., et al. (2017). Infectious Entry and Neutralization of Pathogenic JC Polyomaviruses. Cel Rep. 21, 1169-1179. doi:10.1016/j.celrep.2017.10.027

Gou, W.-F., Zhao, S., Shen, D.-F., Yang, X.-F., Liu, Y.-P., Sun, H.-Z., et al. (2015). The Oncogenic Role of JC Virus T Antigen in Lens Tumors without Cell Specificity of Alternative Splicing of its Intron. Oncotarget 6, 8036-8045. doi:10.18632/oncotarget.3507

Guillory, B., Sakwe, A. M., Saria, M., Thompson, P., Adhiambo, C., Koumangoye, R., et al. (2010). Lack of Fetuin-A ( $\alpha 2$-HS-Glycoprotein) Reduces Mammary Tumor Incidence and Prolongs Tumor Latency via the Transforming Growth Factor- $\beta$ Signaling Pathway in a Mouse Model of Breast Cancer. Am. J. Pathol. 177, 2635-2644. doi:10.2353/ajpath.2010.100177

Hachana, M., Amara, K., Ziadi, S., Gacem, R. B., Korbi, S., and Trimeche, M. (2012). Investigation of Human JC and BK Polyomaviruses in Breast Carcinomas. Breast Cancer Res. Treat. 133, 969-977. doi:10.1007/s10549011-1876-5

Haley, S. A., O'Hara, B. A., and Atwood, W. J. (2020). Adipocyte Plasma Membrane Protein (APMAP) Promotes JC Virus (JCPyV) Infection in Human Glial Cells. Virology 548, 17-24. doi:10.1016/j.virol.2020.06.002

Hayashi, H., Endo, S., Suzuki, S., Tanaka, S., Sawa, H., Ozaki, Y., et al. (2001). JC Virus Large T Protein Transforms Rodent Cells but Is Not Involved in Human Medulloblastoma. Neuropathology 21, 129-137. doi:10.1046/j.14401789.2001.00384.x

Hogan, T. F., Padgett, B. L., Walker, D. L., Borden, E. C., and Frias, Z. (1983). Survey of Human Polyomavirus (JCV, BKV) Infections in 139 Patients with Lung Cancer, Breast Cancer, Melanoma, or Lymphoma. Prog. Clin. Biol. Res. $105,311-324$.

Khalili, K., Gordon, J., and White, M. K. (2006). The Polyomavirus, JCV and its Involvement in Human Disease. Adv. Exp. Med. Biol. 577, 274-287. doi:10.1007/0-387-32957-9_20

Ksiaa, F., Ziadi, S., Mokni, M., Korbi, S., and Trimeche, M. (2010). The Presence of JC Virus in Gastric Carcinomas Correlates with Patient's Age, Intestinal Histological Type and Aberrant Methylation of Tumor Suppressor Genes. Mod. Pathol. 23, 522-530. doi:10.1038/modpathol.2009.184

Kutsuna, T., Zheng, H., Abdel-Aziz, H. O., Murai, Y., Tsuneyama, K., Furuta, I., et al. (2008). High JC Virus Load in Tongue Carcinomas May Be a Risk Factor for Tongue Tumorigenesis. Virchows Arch. 452, 405-410. doi:10.1007/s00428007-0534-0

London, W., Houff, S., Madden, D., Fuccillo, D., Gravell, M., Wallen, W., et al. (1978). Brain Tumors in Owl Monkeys Inoculated with a Human Polyomavirus (JC Virus). Science 201, 1246-1249. doi:10.1126/science.211583

Malekpour Afshar, R., Mollaei, H. R., Zandi, B., and Iranpour, M. (2016). Evaluation of JC and Cytomegalo Viruses in Glioblastoma Tissue. Asian Pac. J. Cancer Prev. 17, 4907-4911. doi:10.22034/APJCP.2016.17.11.4907

Malhotra, J., Waterboer, T., Pawlita, M., Michel, A., Cai, Q., Zheng, W., et al. (2016). Serum Biomarkers of Polyomavirus Infection and Risk of Lung Cancer in Never Smokers. Br. J. Cancer 115, 1131-1139. doi:10.1038/bjc.2016.285

Miller, N. R., McKeever, P. E., London, W., Padgett, B. L., Walker, D. L., and Wallen, W. C. (1984). Brain Tumors of Owl Monkeys Inoculated with JC Virus Contain the JC Virus Genome. J. Virol. 49, 848-856. doi:10.1128/jvi.49.3.848856.1984

Murai, Y., Zheng, H.-C., Aziz, H. O. A., Mei, H., Kutsuna, T., Nakanishi, Y., et al. (2007). High JC Virus Load in Gastric Cancer and Adjacent Non-cancerous Mucosa. Cancer Sci. 98, 25-31. doi:10.1111/j.1349-7006.2006.00354.x

Noch, E., Sariyer, I. K., Gordon, J., and Khalili, K. (2012). JC Virus T-Antigen Regulates Glucose Metabolic Pathways in Brain Tumor Cells. PLoS One 7, e35054. doi:10.1371/journal.pone.0035054

Noguchi, A., Kikuchi, K., Ohtsu, T., Yoshiwara, M., Nakamura, Y., Miyagi, Y., et al. (2013). Pulmonary Tumors Associated with the JC Virus T-Antigen in a Transgenic Mouse Model. Oncol. Rep. 30, 2603-2608. doi:10.3892/or.2013.2782

Nosho, K., Shima, K., Kure, S., Irahara, N., Baba, Y., Chen, L., et al. (2009). JC Virus T-Antigen in Colorectal Cancer Is Associated with P53 Expression and Chromosomal Instability, Independent of $\mathrm{CpG}$ Island Methylator Phenotype. Neoplasia 11, 87-95. doi:10.1593/neo.81188

Nukuzuma, S., Nakamichi, K., Kameoka, M., Sugiura, S., Nukuzuma, C., Tasaki, T., et al. (2016). Suppressive Effect of Topoisomerase Inhibitors on JC Polyomavirus Propagation in Human Neuroblastoma Cells. Microbiol. Immunol. 60, 253-260. doi:10.1111/1348-0421.12372

Piña-Oviedo, S., De León-Bojorge, B., Cuesta-Mejías, T., White, M. K., OrtizHidalgo, C., Khalili, K., et al. (2006). Glioblastoma Multiforme with Small Cell Neuronal-like Component: Association with Human Neurotropic JC Virus. Acta Neuropathol. 111, 388-396. doi:10.1007/s00401-006-0050-3

Querido, S., Fernandes, I., Weigert, A., Casimiro, S., Albuquerque, C., Ramos, S., et al. (2020). High-grade Urothelial Carcinoma in a Kidney Transplant Recipient after JC Virus Nephropathy: The First Evidence of JC Virus as a Potential Oncovirus in Bladder Cancer. Am. J. Transpl. 20, 1188-1191. doi:10.1111/ajt.15663

Ramamoorthy, S., Devaraj, B., Miyai, K., Luo, L., Liu, Y.-T., Boland, C. R., et al. (2011). John Cunningham Virus T-Antigen Expression in Anal Carcinoma. Cancer 117, 2379-2385. doi:10.1002/cncr.25793

Reddi, A., Patel, N., and Morris, N. A. (2019). Diffuse Large B Cell Lymphoma Secondary to JC Virus in Progressive Multifocal Leukoencephalopathy. J. Neurovirol. 25, 883-886. doi:10.1007/s13365-019-00760-z

Reiss, K., and Khalili, K. (2003). Viruses and Cancer: Lessons from the Human Polyomavirus, JCV. Oncogene 22, 6517-6523. doi:10.1038/sj.onc.1206959

Reviriego-Mendoza, M. M., and Frisque, R. J. (2011). Interaction and Colocalization of JC Virus Large $\mathrm{T}$ Antigen and the F-Box Protein $\beta$-transducin-repeat Containing Protein. Virology 410, 119-128. doi:10.1016/ j.virol.2010.10.038

Sariyer, I. K., Merabova, N., Patel, P. K., Knezevic, T., Rosati, A., Turco, M. C., et al. (2012). Bag3- Induced Autophagy Is Associated with Degradation of JCV Oncoprotein, T-Ag. PLoS One 7, e45000. doi:10.1371/journal.pone.0045000

Saxena, R., Saribas, S., Jadiya, P., Tomar, D., Kaminski, R., Elrod, J. W., et al. (2021). Human Neurotropic Polyomavirus, JC Virus, Agnoprotein Targets Mitochondrion and Modulates its Functions. Virology 553, 135-153. doi:10.1016/j.virol.2020.11.004

Shen, C.-H., Wu, J.-D., Hsu, C.-D., Jou, Y.-C., Lin, C.-T., Wang, M., et al. (2011). The High Incidence of JC Virus Infection in Urothelial Carcinoma Tissue in Taiwan. J. Med. Virol. 83, 2191-2199. doi:10.1002/jmv.22240

Shoraka, H. R., Abobakri, O., Naghibzade Tahami, A., Mollaei, H. R., Bagherinajad, Z., Malekpour Afshar, R., et al. (2020). Prevalence of JC and BK Viruses in Patients with Colorectal Cancer: A Systematic Review and Meta- Analysis. Asian Pac. J. Cancer Prev. 21, 1499-1509. doi:10.31557/apjcp.2020.21.6.1499 
Sinagra, E., Raimondo, D., Gallo, E., Stella, M., Cottone, M., Orlando, A., et al. (2014). Could JC Virus Provoke Metastasis in colon Cancer?. World J. Gastroenterol. 20, 15745-15749. doi:10.3748/wjg.v20.i42.15745

Tzeng, Y. J., Guhl, E., Graessmann, M., and Graessmann, A. (1993). Breast Cancer Formation in Transgenic Animals Induced by the Whey Acidic Protein SV40 T Antigen (WAP-SV-T) Hybrid Gene. Oncogene 8, 1965-1971.

Uleri, E., Beltrami, S., Gordon, J., Dolei, A., and Sariyer, I. K. (2011). Extinction of Tumor Antigen Expression by SF2/ASF in JCV-Transformed Cells. Genes \& Cancer 2, 728-736. doi:10.1177/1947601911424578

Vilkin, A., and Niv, Y. (2011). Association between hMLH1 Hypermethylation and JC Virus (JCV) Infection in Human Colorectal Cancer (CRC). Clin. Epigenet 2, 1-5. doi:10.1007/s13148-010-0013-3

Wang, J.-P., Wang, Z.-Z., Zheng, Y.-S., Xia, P., Yang, X.-H., Liu, Y.-P., et al. (2012). JC Virus Existence in Chinese Gastrointestinal Carcinomas. Oncol. Lett. 3, 1073-1078. doi:10.3892/ol.2012.627

White, M. K., and Khalili, K. (2005). Expression of JC Virus Regulatory Proteins in Human Cancer: Potential Mechanisms for Tumourigenesis. Eur. J. Cancer 41, 2537-2548. doi:10.1016/j.ejca.2005.08.019

Zhao, G.-F., Zhao, S., Liu, J.-J., Wu, J.-C., He, H.-Y., Ding, X.-Q., et al. (2017). Cytokeratin 19 Promoter Directs the Expression of Cre Recombinase in Various Epithelia of Transgenic Mice. Oncotarget 8, 18303-18311. doi:10.18632/oncotarget.15435

Zheng, H., Murai, Y., Hong, M., Nakanishi, Y., Nomoto, K., Masuda, S., et al. (2007). JC [corrected] Virus Detection in Human Tissue Specimens. J. Clin. Pathol. 60, 787-793. doi:10.1136/jcp.2006.040915
Zheng, H., Aziz, H. A., Nakanishi, Y., Masuda, S., Saito, H., Tsuneyama, K., et al. (2007). Oncogenic Role of JC Virus in Lung Cancer. J. Pathol. 212, 306-315. doi:10.1002/path.2188

Zheng, H. C., Yan, L., Cui, L., Guan, Y. F., and Takano, Y. (2009). Mapping the History and Current Situation of Research on John Cunningham Virus - a Bibliometric Analysis. BMC Infect. Dis. 9, 28. doi:10.1186/1471-2334-9-28

Conflict of Interest: The authors declare that the research was conducted in the absence of any commercial or financial relationships that could be construed as a potential conflict of interest.

Publisher's Note: All claims expressed in this article are solely those of the authors and do not necessarily represent those of their affiliated organizations, or those of the publisher, the editors and the reviewers. Any product that may be evaluated in this article, or claim that may be made by its manufacturer, is not guaranteed or endorsed by the publisher.

Copyright (c) 2021 Zheng, E, Cui, Zhao and Zhang. This is an open-access article distributed under the terms of the Creative Commons Attribution License (CC BY). The use, distribution or reproduction in other forums is permitted, provided the original author(s) and the copyright owner(s) are credited and that the original publication in this journal is cited, in accordance with accepted academic practice. No use, distribution or reproduction is permitted which does not comply with these terms. 